\title{
MODELIRANJE UTJECAJA UGLEDA TURISTIČKE DESTINACIJE PRISUTNOG U DRUŠTVENIM MEDIJIMA NA ZADOVOLJSTVO TURISTA
}

\author{
Jelena Mušanović \\ Dr. sc., poslijedoktorandica, Fakultet za menadžment u turizmu i ugostiteljstvu, Sveučilište u Rijeci, \\ Primorska 42, 51410 Opatija, Hrvatska.e-mail: jelenak@fthm.hr
}

\section{SAŽETAK}

Prije pojave korisnički generiranih sadržaja dijeljenje osobnog iskustva i doživljaja turističke ponude u destinaciji bilo je ograničeno na uži krug prijatelja i obitelji. Danas, turisti (korisnici društvenih medija) razmjenjuju mišljenja putem suvremenih medija na mreži na način da oblikuju ugled turističke destinacije i utječu na odluku o putovanju potencijalnih turista. Surha ovog istraživanja je ispitati ugled turističke destinacije prisutan u društvenim medijima i njegov utjecaj na zadovoljstvo turista. Empirijsko istraživanje provedeno je na zapadnoj obali Istre (Hrvatska) primjenom upitnika na uzorku od 305 turista koji su se prije putovanja na društvenim medijima informirali o destinaciji. Primjenom metode parcijalnih najmanjih kvadrata modeliranja strukturnim jednadžbama (PLSSEM) izvršena je analiza procjene strukturnog modela i utjecaja ugleda turističke destinacije prisutnog u društvenim medijima na zadovoljstvo turista. Testirani strukturni model ocjenjuje se važnim i pouzdanim instrumentom za mjerenje utjecaja ugleda turističke destinacije prisutnog u društvenim medijima na zadovoljstvo turista te pruža osnovu za buduća istraživanja i za kontinuirano praćenje poboljšanja ugleda turističke destinacije na društvenim medijima i zadovoljstva turista elementima turističke ponude.

Ključne riječi: ugled turističke destinacije, zadovoljstvo turista, društveni mediji, modeliranje, multivarijatna statistička analiza

\section{UVOD}

Turistička destinacija predstavlja mjesto susreta turističke ponude i potražnje te njezin uspjeh između ostaloga ovisi i o njezinom ugledu. Potencijalni turisti koji nemaju prethodnog iskustva s destinacijom u koju putu, svojom percepcijom ugleda turističke destinacije nastoje smanjiti rizik od krivog odabira turističke destinacije (Spence, 1973). Pozitivan ugled, s gledišta ponude, povećava zadovoljstvo turista (Su et al., 2018), utječe na konkurentsku prednost destinacije te 
pomaže u pridobivanju potencijalnih turista, investitora, kvalificirane radne snage (Darwish, Burns, 2019), povećava profit porastom prihoda od prodaje, povećava cijene usluga, smanjuje operativne troškove (Darwish, Burns, 2019) te utječe na percipiranu vrijednost i lojalnost turista (Vengesayi, 2003; Morgan et al., 2011; Minghetti, Celotto, 2015).

Od samih početaka, od kada ljudi putuju, sektor turizma prilagođavao se tehnološkom razvoju i izazovu. U eri digitalizacije se te promjene događaju rapidno. Prema UNWTO (2019), godišnje putuje oko 1,4 milijardi ljudi na svijetu što ukazuje na podatak da međunarodni turizam nastavlja nadmašivati globalnu ekonomiju, ali isto tako pokazuje kako mala promjena u sektoru ima veliki utjecaj na cijelo društvo (Urška Starc et al., 2019).

Prije pojave korisnički generiranih sadržaja dijeljenje osobnog iskustva i doživljaja turističke ponude u destinaciji bilo je ograničeno na uži krug prijatelja i obitelji. Rast Web 2.0 tehnologija i društvenih medija omogućio je razvoj korisnički generiranih sadržaja (engl. user-generated content - UGC) te objavu komentara, recenzija i mišljenja na mrežnim sjedištima kao što su Tripadvisor, Facebook, Youtube, Instragram i Twitter. S obzirom na to da se turističke usluge u destinaciji ne mogu unaprijed konzumirati, važno je naglasiti da gosti imaju povjerenja u recenzije objavljene na društvenim medijima (Ip et al., 2010; Filieri, 2015; Gretze, Yoo, 2008).

Prema podacima We Are Social, u 2019. godini oko 45 \% ljudi svjetske populacije su aktivni korisnici društvenih medija. Prema podacima Digital Report-a (Kemp, 2019), procjenjuje se da je broj aktivnih korisnika Facebooka dosegao 2,1 milijardi ljudi diljem svijeta. Prema istraživanju TOMAS ljeto Stavovi i potrošnja turista u Hrvatskoj za 2017. godinu, internetom se kao izvorom informacija koristilo gotovo $44 \%$ ispitanika, a gosti su najčešće prikupljali informacije putem interneta (44\%); slijede mediji (25\%), preporuke rodbine i prijatelja (24\%) te prijašnji boravak (18\%). Promatrajući internet kao izvor informacija, $67 \%$ ispitanika pretraživalo je informacije na društvenim medijima, $50 \%$ na online turističkim agencijama, $45 \%$ na stranicama hrvatskih turističkih zajednica/ureda te 44,4\% na stranicama smještajnih objekata (Institut za turizam, 2018).

U literaturi se navodi da je zadovoljstvo turista pokazatelj namjere povratka u destinaciju (Chen, Tsai, 2007; Triantafillidou, Petala, 2016). Također, zadovoljstvo turista pozitivno utječe na destinaciju na način da joj pomaže u ostvarivanju ekonomskih ciljeva poput povećanja ukupnog broja turista, prihoda i konkurentnosti turističke destinacije, što pogoduje destinaciji i nositeljima turističke ponude da budu održivi i profitabilniji (Akama, Kieti, 2003; Hapenciuc, Condratov, 2007; Wu, Ko, 2013; Saayman et al., 2018).

Slijedom navedenoga, postavlja se sljedeće istraživačko pitanje: utječe li ugled turističke destinacije prisutan u društvenim medijima, temeljen na korisnički generiranim sadržajima, na zadovoljstvo turista? Svrha ovog rada je: a) ispitati profil turista koji su se prije putovanja informirali o destinaciji u koju putuju na društvenim medijima; b) ispitati ugled turističke destinacije na društvenim medijima; c) ispitati zadovoljstvo turista elementima ponude turističke destinacije; d) ispitati valjanost i pouzdanost strukturnog modela; e) ispitati postojanost utjecaja ugleda turističke destinacije prisutnog u društvenim medijima na zadovoljstvo turista. 
Rad je podijeljen u četiri cjeline. U uvodnom dijelu naglašava se problematika istraživanja. Nakon uvoda slijedi analiza prethodnih istraživanja vezanih uz ugled turističke destinacije na društvenim medijima i zadovoljstva turista te postavljanje hipoteza. Zatim se elaboriraju rezultati deskriptivne i multivarijatne statističke analize koja se temelji na analizi strukturnog modeliranja jednadžbama primjenom metode najmanjih kvadrata. Na kraju se rezimiraju rezultati i uspoređuju s prethodnim sličnim istraživanjima, navode ograničenja u istraživanju te daje doprinos istraživanja.

\section{KORISNIČKI GENERIRANI SADRŽAJI NA DRUŠTVENIM MEDIJIMA}

Trend dijeljena iskustva, preporuke, mišljenja, fotografije i videozapise s drugim korisnicima društvenih medija na mrežnim stranicama započeo je razvojem elektroničkih aplikacija Web 2.0 i Travel 2.0. koje se omogućile kreiranje korisnički generiranog sadržaja (engl. user generated content - UGC). Potencijalni turisti, između ostaloga, koriste korisničke generirane sadržaje kako bi se informirali o kvaliteti proizvoda i usluga, smanjili rizika i povećali percepciju o sigurnosti u destinaciji, izbjegli mogući nesklad informacija i rizik krivog odabira turističke destinacije (Kim, Mattila, 2011). Iz teorije signala (Spence, 1973) proizašla je pretpostavka da neke vidljive osobine ljudi mogu poslužiti kao znak ili upozorenje o kvaliteti i neskladu informacija. Ako poruke na društvenim medijima odašilju znak o kvaliteti turističkih sadržaja te ako se većina drugih turista složi da je vrijedno posjetiti turističku destinaciju, informacija će se percipirati kao istinita (Marchiori, 2012). Potrebno je naglasiti da se sadržaji objavljeni na društvenim medijima smatraju vrlo pouzdanim izvorom informacija (Xiang, Gretzel, 2010). Svaki bi pojedinac svojim stavom prema komentarima na društvenim medijima, pa u konačnici i ugleda turističke destinacije, trebao moći prepoznati i protumačiti sadržaje komentara u smislu pozitivne ili negativne jednostranosti poruke te sveukupne dosljednosti mišljenja podijeljenih na društvenim medijima. Prema rezultatima istraživanja nekolicine autora, korisnički generirani sadržaji znatno utječu na proces donošenja odluka o putovanju i to u fazi prije, tijekom i nakon putovanja (De Souza, Costa Machado, 2017; Fotis et al., 2012; Kim, Mattila, 2011).

Korisnički generirani sadržaj se u ovom radu razmatra kroz poslanu poruku, odnosno snagu argumenta, jednostranost poruke i dosljednost poruke. Snaga argumenta odnosi se na kvalitetu primljenih informacija, odnosno to je mjera u kojoj primatelj poruke prihvaća argument kao uvjerljiv ili valjan u podržavanju njegova mišljenja (Cheung et al., 2009). Jednostranost poruke sačinjavaju pozitivni ili negativni čimbenici ponude turističke destinacije, a ne oboje (Hastak, Park, 1990). Međutim, primanje informacije o pozitivnim i negativnim značajkama upotpunjuje informaciju i smatraju se vjerodostojnijima (Kamins, Marks, 1988). Naposljetku, dosljednost poruke ogleda se u kojoj mjeri je elektronička preporuka (eWoM) u skladu s iskustvima drugih turista koji ocjenjuju isti turistički proizvod ili uslugu.

\section{UGLED TURISTIČKE DESTINACIJE NA DRUŠTVENIM MEDIJIMA}

Pojam ugled je teško definirati zbog raznih pristupa, perspektiva i disciplina, a posebice ako se primjenjuje na mrežnim sjedištima ili ako se u obzir uzme da svaki promatrač različito percipira ugled. $U$ vidu ovog istraživanja ugled se promatra sa online aspekta. Einwiller (2003) ugled na 
mreži definira kao komunikacijske i interaktivne postupke koji služe za dijeljenje informacija koje razmjenjuju korisnici društvenim medijima. Marchiori et al. (2011) definiraju ugled na mreži kao mišljenja interesno-utjecajnih skupina izražena korisnički generiranim sadržajima.

Ugled nastaje kao posljedica verbalizacije imidža i predstavlja neopipljivu vrijednost destinacije i nositelja turističke ponude. Shvaćanje značenja ugleda turističke destinacije kao neopipljive vrijednosti postalo je tema znanstvenih istraživanja (Díaz, Rodríguez, 2017; Marchiori et al., 2013; Marinao Artigas, 2017; Su et al., 2018) otkada je ustanovljeno da je pozitivni ugled neopipljivo dobro turističke destinacije koje može utjecati na imidž destinacije (LeBlanc, Nguyen, 1996; Marinao et al., 2012), percepciju vrijednosti i lojalnosti turista prema destinaciji (Christou, 2007), zadovoljstvo (Loureiro, Kastenholz, 2011) te je, naposljetku, jamstvo održivog razvoja (Mingchuan, 2015).

Različiti su pristupi analizi ugleda turističke destinacije. Autori Marchiori et al. (2010) razvili su valjan model za razumijevanje ugleda turističke destinacije na mreži. Tri godine kasnije, Marchiori et al. (2013) dolaze do spoznaje da postoji statistička značajna povezanost između konstrukata (stav prema ugledu na društvenim medijima, snaga argumenta, jednostranost poruke, dosljednost poruke, stav povjerenja u društvene medije, percipirani ugled na društvenim medijima), dok je najslabija povezanost dokazana između percepcije prevladavajućih mišljenja i povjerenja u konverzacije na mreži. Autori Marinao Artigas et al. (2015) koristili su strukturno modeliranje jednadžbama (SEM) u svrhu mjerenja medijacijske uloge prisnosti između kognitivne percepcije i afektivne procjene ugleda. Autori Micera i Crispino (2017) su kvantitativno-kvalitativnim metodama istraživanje spoznali da su najčešće raspravljane teme na društvenim medijima bile umjetnost, kultura i događaj, catering i kupovina, usluge, prijevoz i promet, dok su sigurnost i urbana kvaliteta najmanje diskutirane teme na društvenim medijima. Autori Inversini i Cantoni (2011) istraživali su turističku destinaciju na mreži i opisali tržište na Google i Yahoo! tražilicama u svrhu dobivanja spoznaja o razumijevanju uloge korisnički generiranih sadržaja pri stvaranju ugleda turističke destinacije na mreži. Autori su zaključili da turističke destinacije trebaju u potpunosti upravljati ugledom na mreži tako da prate rasprave i koriste se njima u marketinške i druge svrhe. Naposljetku, Su et al. (2018) su primjenom strukturnog modeliranja direktan potvrdili direktan utjecaj ugleda turističke destinacije na zadovoljstvo turista.

$\mathrm{Na}$ temelju prikaza istraživanja može se zaključiti da se proučavanjem ugleda turističke destinacije na mreži i njezinih čimbenika bavili nedovoljno istraživača te da postoji mnogo prostora za modifikaciju modela ugleda destinacije, njezinih čimbenika i prethodnica.

\section{ZADOVOLJSTVO TURISTA}

Od 1960-ih godina prošloga stoljeća, znanstvenici su proveli mnoga istraživanja na temu zadovoljstva turista, i to iz perspektive menadžmenta kvalitete i namjere ponovne kupnje (Chen et al., 2013). Pizam et al. (1978) primijenili su koncept zadovoljstva klijenta u istraživanju turizma, što je dovelo do iznimne popularnosti teme u znanstvenim istraživanjima turizma, jer zadovoljstvo predstavlja snažan pokazatelj namjere ponovnog odlaska u destinaciju i spremnost da se destinacija preporuči drugima. 
Mnogo se pozornost pridavalo istraživanju zadovoljstvu turista u uslužnim djelatnostima kao jednom od glavnih ciljeva poslovanja koji utječe na: odabir destinacije, potrošnju turističkih proizvoda i usluga, na odluku o ponovnoj posjeti destinaciji, ali i na uspješnost poslovanja na konkurentnom tržištu (Kozak, Rimmington, 2000). Istraživanja zadovoljstva turista usredotočena su na različite proizvode i usluge, kao što su usluge smještaja (Ammissah, 2013; Udit, Kalyan, 2017), restorana (Chadee, Mattsson, 1996), turističkih atrakcija (Agyeiwaah et al., 2016; Jensen et al., 2017), turističkih tura (Lee, 2015), ali i na zadovoljstvo turističkom destinacijom (Alegre, Cladera, 2006; Kozak, 2001; Yu, Goulden, 2006; Puh, 2014; Soldić Frleta, Smolčić Jurdana, 2018).

Koncept zadovoljstvo turista određuju prethodnice i posljedice zadovoljstva turista. U prethodnice zadovoljstva turista ubrajaju se najčešće kvaliteta usluge, očekivana i percipirana vrijednost, imidž i ugled (Yap et al., 2018; Jiang et al., 2018; Su et al., 2018; Wang et al., 2009). Posljedice zadovoljstva turista rezultat su zadovoljstva turista, a sagledavaju se kao namjere u ponašanju turista, što najčešće uključuje lojalnost i pritužbe (Yap et al., 2018; Saayman et al., 2018).

Zadovoljstvo turista mjeri se pomoću dimenzija. Autori Kozak i Rimmington (2000) ispitivali su zadovoljstvo turista te su izlučene četiri dimenzije koje opisuju zadovoljstvo turista: privlačnost destinacije, turističke znamenitosti i sadržaji, poznavanje (korištenje) engleskog jezika, sadržaji i usluge u zračnoj luci. Golob et al. (2014) istraživali su kvalitetu i razinu zadovoljstva turističkom ponudom grada Umaga na uzorku od 200 ispitanika. Izlučene dimenzije su: prostor, klima, okoliš, stanovništvo i zaposleni, organiziranost destinacije, sadržaji usko su povezane s destinacijom, a ispitani turisti pokazali su visoku razinu zadovoljstva klimom i vremenskim prilikama, ponudom smještaja, gostoljubivošću stanovništva i ljubaznošću zaposlenika. Autori Soldić Frleta i Smolčić Jurdana (2018) istraživali su razlike u razini zadovoljstva turista različitim elementima urbanih turističkih destinacija i čimbenike koji određuju zadovoljstvo turista u glavnoj sezoni i izvan sezone. Metodom analize glavnih komponenata izlučeni su sljedeći faktori: prijevoz i informacije, sadržaji i vrijednost za novac, okruženje, kvaliteta, sigurnost i gostoljubivost. Analizom sadržaja dimenzija može se zaključiti kako su dimenzije dostupnost destinacije, atrakcije, aktivnosti, cijena, smještaj, sigurnost, okoliš znamenitosti, sadržaji u destinaciji, dostupnost i cijena najčešće upotrebljavane dimenzije u mjerenju i opisivanju zadovoljstva turista turističkom destinacijom.

Nadalje, Gnoth (1997) je u istraživanju zadovoljstva turista istaknuo da turisti mogu negativno procijeniti svoj boravak u destinaciji ako postoji razlika između oglašavanja godišnjeg odmora i stvarnog iskustva i doživljaja. Kako bi se postigao pozitivan ugled na mreži, turističke destinacije i nositelji turističke ponude moraju pružiti ono što je obećano jer je svaki pojedinac potencijalno slobodan izraziti svoje mišljenje objavom komentara na društvenim ili drugim medijima te se tako stvara pozitivni ili negativni ugled turističke destinacije na društvenim medijima. Među ostalim, pozitivni ugled najvažniji je resurs u razvijanju neopipljivih vrijednosti turističke destinacije $i$ predstavlja presudan čimbenik uspjeha turističke destinacije, što rezultira zadovoljstvom turista (Su et al., 2018) i konkurentskom prednošću turističke destinacije (Dolphin, 2004; Pruzan, 2001).

Slijedom navedenoga postavljene su tri istraživačke hipoteze:

$\mathrm{H}_{1}$ : Postoji statistički značajan utjecaj sadržaja poruka na ugled turističke destinacije prisutnih u društvenim medijima. 
$\mathrm{H}_{2}$ : Postoji statistički značajan utjecaj stava prema komentarima na ugled turističke destinacije prisutnih u društvenim medijima.

$\mathrm{H}_{3}$ : Postoji statistički značajan utjecaj ugleda turističke destinacije prisutnog u društvenim medijima na zadovoljstva turista.

U nastavku ovog rada detaljno se opisuje metodologija empirijskog istraživanja koja obuhvaća operacionalizaciju upitnika i mjernih konstrukata strukturnog modela te se iznose rezultati istraživanja.

\section{METODOLOGIJA EMPIRIJSKOG ISTRAŽIVANJA}

\section{1 Instrument istraživanja i operacionalizacija konstrukata}

Upitnik je definiran na temelju prethodno razvijenih $i$ testiranih mjernih instrumenata i ljestvica kako bi zadovoljio potrebne metrijske karakteristike (valjanost, pouzdanost, objektivnost, osjetljivost, primjenjivost i sl.). Mjerne ljestvice originalno su razvijene na engleskome jeziku, što je zahtijevalo ponovnu provjeru njihove valjanosti na hrvatskome, njemačkome i talijanskome jeziku. Latentne varijable reflektivnog i formativnog su karaktera te su mjerene na Likertovoj ljestvici slaganja i zadovoljstva s pet ocjena.

Reflektivna latentna varijabla sadržaj poruka na društvenim medijima mjerena je pomoću osam čestica preuzetih od autora Marchiori et al. (2013). Latentna varijabla stav prema komentarima na društvenim medijima mjerena je sa šest čestica preuzetih od Marchiori et al. (2013). Ugled turističke destinacije na društvenim medijima središnja je i reflektivna latentna varijabla konceptualnog modela te se mjerila s pet čestica sadržanih u instrumentu istraživanja koju su razvili Marinao Artigas et al. (2015). Zadovoljstvo turista elementima turističke ponude formativna je latentna varijabla koja se temelji na istraživanju Instituta za turizam (2015) - Tomas ljeto 2014 - Stavovi i potrošnja turista u Hrvatskoj. Ljestvica je mjerena s 23 elementa turističke ponude.

\subsection{Odabir ciljne skupine}

Skup jedinica populacije čine turisti koji su se prije putovanja na društvenim medijima informirali o turističkoj destinaciji (plavoj Istri). Ispitanici u uzorku izabrani su po načelu prigodnog uzorka te je prilikom ispitivanja postavljeno eliminacijsko pitanje „Jeste li se prije putovanja na društvenim medijima informirali o turističkoj destinaciji?". Istraživanje je provedeno od početka srpnja do kraja rujna 2016. i 2017. godine kako bi se primarno ispitivalo za vrijeme glavne turističke sezone i prikupio što veći uzorak. Gruba procjena minimalne veličine uzorka treba biti deset puta veća od broja formativnih manifestnih varijabli latentnog konstrukta (Hair et al., 2014by Hair, Hult, Ringle, and Sarstedt, provides a concise yet very practical guide to understanding and using PLS structural equation modeling (PLS-SEM). Prema tome, minimalna veličina uzorka iznosi 230 , a veličina prikupljenog uzorka 305. 


\subsection{Metode statističke analize podataka}

Kako bi se što kvalitetnije analizirali i interpretirali rezultati te testirale znanstvene hipoteze istraživanja primijenjene su univarijatna i multivarijatna statistička analiza. Metodom deskriptivne statističke analize sistematiziran je i opisan uzorak istraživanja te su izračunati osnovni parametri statističke analize. Modeliranjem strukturnim jednadžbama primjenom parcijalnih najmanjih kvadrata ispituje se strukturni odnos između latentnih i manifestnih varijabli. Složenost metode očituje se kroz objedinjavanje faktorske i regresijske analize i drugih statističkih metoda. Primjena PLS-SEM-a u analizi primarnih podataka ovog rada smatra se opravadnim iz sljedećih razloga: a) podržava ciljeve i problem istraživanja; b) testira novije teorije istraživanja (Henseler et al., 2009); c) daje stabilne izračune parametara kada se vanjski model sastoji od formativnih i reflektivnih manifestnih varijabli (Ringle et al., 2012); d) podržava mali uzorak prikupljenih podataka (Hair et al., 2017). Prema navodima autora, PLS-SEM je robustan model, jer tranformira podatke u skladu $s$ neutralnim graničnim teoremom kada su narušene parametrijske pretpostavke normalno raspodjeljenih podataka i kada nije osigurana neovisnost opažanja (Hair et al., 2011; Ringle et al., 2009; Orehovački, 2013).

\section{REZULTATI EMPIRIJSKOG ISTRAŽIVANJA}

\subsection{Rezultati deskriptivne statističke analize}

Analiza obilježja ispitanika prema rodu pokazuje da je u ukupnom uzorku bilo 57,4 \% muškaraca i 42,6 \% manje žena. Prosječna starosna dob ispitanika iznosi 40,6 godina ( $s=11,6$. Struktura ispitanika visoko je obrazovana, od čega 31,8 \% ispitanika ima završen fakultet i 38,0 \% višu školu. Uzorak obuhvaća 96,7 \% stranih ispitanika (turista). Većina ispitanika dolazi iz Njemačke (37,4 \%), Italije (22,3 \%) i Austrije (13,1 \%), koji su i tradicionalno najbrojniji gosti u Istarskoj županiji.

Pri planiranju putovanja, ukupno $72,8 \%$ ispitanika redovito ili povremeno traži informacije o destinaciji na društvenim medijima i na mreži. Ukupno 49,8 \% ispitanika čita recenzije drugih korisnika putem turističkih mrežnih portala, dok 46,2 \% upotrebljava društvene medije kao izvor informacija. Ispitanici najpouzdanijim izvorom informacija smatraju one koje pružaju aktualne informacije $(52,5 \%)$ i one koji imaju poturde drugih korisnika izraženih s brojem lajkova (42,6\%). Na pitanje mogu li sadržaji generirani od strane drugih turista (komentari, slike i video objave) utjecati na promjenu njihove odluke o odabiru destinacije, 46,6\% ispitanika je odgovorilo s da, dok je 41,6\% ispitanika odgovorilo s ne.

U Tablici 1 prikazani su osnovni parametri deskriptivne statističke analize latentnih i manifestnih varijabli. Sadržaj poruka na društvenim medijima ocijenjen je prosječnom ocjenom 3,41. Ispitanici se slažu da komentari uključuju prednosti i mane destinacije $(\bar{x}=3,67)$ te da komentari naglašavaju pozitivne strane destinacije $(\bar{x}=3,60)$, dok se najmanje slažu s izjavom da su autori komentara imali slična iskustva u destinaciji $(\bar{x}=3,24)$ i da komentari imaju snažnu poruku $(\bar{x}=3,25)$.

Ukupna ocjena stava prema komentarima na društvenim medijima ocijenjena je prosječnom ocjenom 3,48. Ispitanici su najviše okupirani pokušajem da doznaju jesu li drugi korisnici doživjeli iskustvo koje bi oni željeli doživjeti ( $\bar{x}=3,80$ ). Najmanje pozornosti posvećuju prepoznavanju 
komentara koji se razlikuju od vecine objavljenih komentara o destinaciji $(\bar{x}=3,31)$ te koji aspekti destinacije imaju lošiji ugled na društvenim medijima $(\bar{x}=3,32)$.

Ugled turističke destinacije na društvenim medijima ocijenjen je prosječnom ocjenom 3,76. Ispitanici se najviše slažu s izjavom da korisnici na društvenim medijima pozitivno pričaju o destinaciji ( $\bar{x}=$ $3,97)$ i da je destinacija visoko cijenjena $(\bar{x}=3,92)$. Najnižom prosječnom ocjenom ocijenili su izjavu mislim da korisnici na društvenim medijima imaju zajednički stav o destinaciji $(\bar{x}=3,10)$ i destinacija u usporedbi s drugim sličnim destinacijama ima bolji ugled na društvenim medijima $(\bar{x}=3,29)$.

Prema rezultatima iz Tablice 2 može se zaključiti da je vrlo dobre rezultate za zapadni dio Istre dao pokazatelj zadovoljstva elementima turističke ponude $(\bar{x}=3,80)$. Da su ispitanici vrlo zadovoljni, potvrdilo je $39,0 \%$ ispitanika koji su označili da se u potpunosti slažu s navedenim tvrdnjama. Ispitanici su posebice zadovoljni ljepotom prirode i krajolika $(\bar{x}=4,45)$, gostoljubivošću lokalnog stanovništva $(\bar{x}=4,17)$ i čistoćom mora $(\bar{x}=4,14)$, dok su manje zadovoljni kvalitetom lokalnog prijevoza $(\bar{x}=3,27)$ te opremljenošću i uređenošću lokalnog prijevoza $(\bar{x}=3,53)$.

Zaključno, prosječne ocjene kreću se u rasponu od 3,14 do 3,80, što ukazuje na slaganje s postavljanim česticama ili tvrdnjama i da u prosjeku ne postoje značajnija odstupanja od prosječnih vrijednosti iz uzorka.

Tablica 1. Deskriptivna statistička analiza čestica $(n=305)$

\begin{tabular}{|c|c|c|c|c|c|}
\hline Kôd & Čestice & $\begin{array}{l}\text { Aritmetička } \\
\text { sredina }\end{array}$ & $\begin{array}{l}\text { Standardna } \\
\text { devijacija }\end{array}$ & $\begin{array}{l}\text { Koeficijent } \\
\text { asimetrije }\end{array}$ & $\begin{array}{l}\text { Koeficijent } \\
\text { zaobljenosti }\end{array}$ \\
\hline \multicolumn{2}{|c|}{$\begin{array}{l}\text { Sadržaj poruka na društvenim } \\
\text { medijima }\end{array}$} & 3,41 & 0,636 & $-0,494$ & $-0,040$ \\
\hline Sadržaj_6 & $\begin{array}{l}\text { Komentari uključuju } \\
\text { prednosti i mane } \\
\text { destinacije. }\end{array}$ & 3,67 & 0,960 & $-0,614$ & 0,244 \\
\hline Sadržaj_4 & $\begin{array}{c}\text { Komentari } \\
\text { naglašavaju pozitivne } \\
\text { strane destinacije. }\end{array}$ & 3,60 & 0,845 & $-0,855$ & 1,062 \\
\hline Sadržaj_7 & $\begin{array}{l}\text { Objavljeni komentari } \\
\text { o destinaciji } \\
\text { međusobno su } \\
\text { usklađeni. }\end{array}$ & 3,50 & 1,033 & $-0,329$ & $-0,294$ \\
\hline Sadržaj_1 & $\begin{array}{l}\text { Komentari su } \\
\text { uvjerljivi. }\end{array}$ & 3,49 & 0,953 & $-0,472$ & $-0,164$ \\
\hline Sadržaj_3 & Komentari su dobri. & 3,45 & 0,906 & $-0,432$ & 0,197 \\
\hline Sadržaj_5 & $\begin{array}{c}\text { Komentari } \\
\text { naglašavaju pozitivna } \\
\text { mišljenja o destinaciji. }\end{array}$ & 3,43 & 0,926 & $-0,020$ & $-0,208$ \\
\hline
\end{tabular}




\begin{tabular}{|c|c|c|c|c|c|}
\hline Kôd & Čestice & $\begin{array}{l}\text { Aritmetička } \\
\text { sredina }\end{array}$ & $\begin{array}{c}\text { Standardna } \\
\text { devijacija }\end{array}$ & $\begin{array}{l}\text { Koeficijent } \\
\text { asimetrije }\end{array}$ & $\begin{array}{l}\text { Koeficijent } \\
\text { zaobljenosti }\end{array}$ \\
\hline Sadržaj_2 & $\begin{array}{l}\text { Komentari imaju } \\
\text { snažnu poruku. }\end{array}$ & 3,25 & 1,011 & $-0,085$ & $-0,325$ \\
\hline Sadržaj_8 & $\begin{array}{c}\text { Autori komentara } \\
\text { imali su slična } \\
\text { iskustva u destinaciji. }\end{array}$ & 3,24 & 1,099 & $-0,539$ & $-0,304$ \\
\hline \multicolumn{2}{|c|}{$\begin{array}{l}\text { Stav prema komentarima na } \\
\text { društvenim medijima }\end{array}$} & 3,48 & 0,782 & $-0,386$ & 0,631 \\
\hline Stav_4 & $\begin{array}{l}\text { Pokušavam doznati } \\
\text { jesu li drugi korisnici } \\
\text { doživjeli iskustvo koje } \\
\text { bih ja želio doživjeti. }\end{array}$ & 3,80 & 1,155 & $-0,822$ & $-0,143$ \\
\hline Stav_3 & $\begin{array}{l}\text { Pokušavam doznati } \\
\text { imaju li drugi } \\
\text { korisnici slične } \\
\text { komentare o } \\
\text { destinaciji. }\end{array}$ & 3,69 & 1,000 & $-0,589$ & $-0,091$ \\
\hline Stav_1 & $\begin{array}{c}\text { Pokušavam } \\
\text { doznati kakav je } \\
\text { ugled destinacije } \\
\text { na društvenim } \\
\text { medijima. }\end{array}$ & 3,53 & 0,977 & $-0,397$ & $-0,145$ \\
\hline Stav_5 & $\begin{array}{c}\text { Pokušavam } \\
\text { prepoznati koji su } \\
\text { ključni komentari o } \\
\text { destinaciji objavljeni } \\
\text { u društvenim } \\
\text { medijima. }\end{array}$ & 3,49 & 1,042 & $-0,189$ & $-0,633$ \\
\hline Stav_2 & $\begin{array}{c}\text { Pokušavam } \\
\text { doznati koji aspekti } \\
\text { destinacije imaju loš } \\
\text { ugled na društvenim } \\
\text { medijima. }\end{array}$ & 3,32 & 1,102 & $-0,447$ & $-0,343$ \\
\hline
\end{tabular}


J. Mušanović: Modeliranje utjecaja ugleda turističke destinacije prisutnog u društvenim medijima na... Zbornik Veleučilišta u Rijeci, Vol. 8 (2020), No. 1, pp. 77-101

\begin{tabular}{|c|c|c|c|c|c|}
\hline Kôd & Čestice & $\begin{array}{l}\text { Aritmetička } \\
\text { sredina }\end{array}$ & $\begin{array}{l}\text { Standardna } \\
\text { devijacija }\end{array}$ & $\begin{array}{l}\text { Koeficijent } \\
\text { asimetrije }\end{array}$ & $\begin{array}{l}\text { Koeficijent } \\
\text { zaobljenosti }\end{array}$ \\
\hline Stav_6 & $\begin{array}{l}\text { Pokušavam } \\
\text { prepoznati } \\
\text { komentare koji } \\
\text { se razlikuju od } \\
\text { većine objavljenih } \\
\text { komentara o } \\
\text { destinaciji. }\end{array}$ & 3,31 & 1,152 & $-0,254$ & $-0,665$ \\
\hline \multicolumn{2}{|c|}{$\begin{array}{l}\text { Ugled turističke destinacije na } \\
\text { društvenim medijima }\end{array}$} & 3,76 & 0,690 & $-0,076$ & $-0,323$ \\
\hline Ugled_4 & $\begin{array}{c}\text { Korisnici na } \\
\text { društvenim medijima } \\
\text { pozitivno pričaju o } \\
\text { destinaciji. }\end{array}$ & 3,97 & 0,673 & $-0,099$ & $-0,409$ \\
\hline Ugled_3 & $\begin{array}{l}\text { Destinacija je visoko } \\
\text { cijenjena. }\end{array}$ & 3,92 & 0,984 & $-0,509$ & $-0,453$ \\
\hline Ugled_5 & $\begin{array}{c}\text { Dobar ugled } \\
\text { destinacije na } \\
\text { društvenim medijima } \\
\text { zasnovan je na } \\
\text { povijesno-kulturnim } \\
\text { znamenitostima } \\
\text { destinacije. }\end{array}$ & 3,81 & 0,972 & $-0,434$ & $-0,410$ \\
\hline Ugled_1 & $\begin{array}{l}\text { Destinacija ima dobar } \\
\text { ugled na društvenim } \\
\text { medijima. }\end{array}$ & 3,78 & 1,097 & $-1,008$ & 0,645 \\
\hline Ugled_2 & $\begin{array}{c}\text { Destinacija u } \\
\text { usporedbi s drugim } \\
\text { sličnim destinacijama } \\
\text { ima bolji ugled } \\
\text { na društvenim } \\
\text { medijima. }\end{array}$ & 3,29 & 0,965 & $-0,436$ & $-0,195$ \\
\hline $\begin{array}{r}\text { Zadovoljs } \\
\text { tur }\end{array}$ & $\begin{array}{l}\text { o turista elementima } \\
\text { tičke ponude }\end{array}$ & 3,80 & 0,618 & $-0,420$ & 0,417 \\
\hline Zadovoljst & $\begin{array}{cc}\text { Ljepota prirode } \\
\text { _ }\end{array}$ & 4,45 & 0,759 & $-1,403$ & 1,667 \\
\hline
\end{tabular}




\begin{tabular}{|c|c|c|c|c|c|}
\hline Kôd & Čestice & $\begin{array}{c}\text { Aritmetička } \\
\text { sredina }\end{array}$ & $\begin{array}{c}\text { Standardna } \\
\text { devijacija }\end{array}$ & $\begin{array}{l}\text { Koeficijent } \\
\text { asimetrije }\end{array}$ & $\begin{array}{l}\text { Koeficijent } \\
\text { zaobljenosti }\end{array}$ \\
\hline Zadovoljstvo_4 & $\begin{array}{c}\text { Gostoljubivost } \\
\text { lokalnog } \\
\text { stanovništva }\end{array}$ & 4,17 & 1,139 & $-1,367$ & 1,060 \\
\hline Zadovoljstvo_3 & Čistoća mora & 4,14 & 0,851 & $-0,525$ & $-0,788$ \\
\hline Zadovoljstvo_21 & $\begin{array}{c}\text { Radno vrijeme } \\
\text { uslužnih } \\
\text { djelatnosti }\end{array}$ & 4,12 & 0,973 & 0,279 & 2,240 \\
\hline Zadovoljstvo_16 & $\begin{array}{l}\text { Mogućnost za } \\
\text { kupnju }\end{array}$ & 3,97 & 0,945 & $-0,546$ & $-0,459$ \\
\hline Zadovoljstvo_5 & $\begin{array}{l}\text { Ljubaznost } \\
\text { zaposlenih u } \\
\text { turizmu }\end{array}$ & 3,96 & 1,046 & $-0,952$ & 0,353 \\
\hline Zadovoljstvo_6 & $\begin{array}{l}\text { Osobna } \\
\text { sigurnost }\end{array}$ & 3,95 & 1,035 & $-1,002$ & 0,650 \\
\hline Zadovoljstvo_8 & $\begin{array}{c}\text { Kvaliteta } \\
\text { ugostiteljskih } \\
\text { objekata }\end{array}$ & 3,87 & 1,111 & $-0,817$ & $-0,175$ \\
\hline Zadovoljstvo_13 & $\begin{array}{c}\text { Ponuda } \\
\text { organiziranih } \\
\text { izleta u okolicu }\end{array}$ & 3,84 & 0,883 & $-0,315$ & $-0,394$ \\
\hline Zadovoljstvo_9 & $\begin{array}{c}\text { Bogatstvo } \\
\text { gastronomske } \\
\text { ponude }\end{array}$ & 3,81 & 1,025 & $-0,471$ & $-0,819$ \\
\hline Zadovoljstvo_15 & $\begin{array}{c}\text { Prometna } \\
\text { dostupnost } \\
\text { mjesta }\end{array}$ & 3,75 & 0,962 & $-0,323$ & $-0,744$ \\
\hline Zadovoljstvo_18 & $\begin{array}{c}\text { Prezentacija } \\
\text { kulturne baštine }\end{array}$ & 3,74 & 1,061 & $-0,673$ & $-0,161$ \\
\hline Zadovoljstvo_7 & $\begin{array}{l}\text { Uređenost } \\
\text { mjesta }\end{array}$ & 3,69 & 0,898 & $-0,286$ & $-0,393$ \\
\hline Zadovoljstvo_10 & $\begin{array}{l}\text { Kvaliteta } \\
\text { informacija } \\
\text { na mrežnim } \\
\text { sjedištima }\end{array}$ & 3,66 & 0,988 & $-0,480$ & 0,041 \\
\hline Zadovoljstvo_2 & $\begin{array}{l}\text { Očuvanost } \\
\text { okoliša }\end{array}$ & 3,65 & 1,037 & $-0,475$ & $-0,191$ \\
\hline
\end{tabular}


J. Mušanović: Modeliranje utjecaja ugleda turističke destinacije prisutnog u društvenim medijima na... Zbornik Veleučilišta u Rijeci, Vol. 8 (2020), No. 1, pp. 77-101

\begin{tabular}{|c|c|c|c|c|c|}
\hline Kôd & Čestice & $\begin{array}{c}\text { Aritmetička } \\
\text { sredina }\end{array}$ & $\begin{array}{c}\text { Standardna } \\
\text { devijacija }\end{array}$ & $\begin{array}{l}\text { Koeficijent } \\
\text { asimetrije }\end{array}$ & $\begin{array}{l}\text { Koeficijent } \\
\text { zaobljenosti }\end{array}$ \\
\hline Zadovoljstvo_11 & $\begin{array}{c}\text { Kvaliteta } \\
\text { informacija u } \\
\text { destinaciji }\end{array}$ & 3,63 & 1,024 & $-0,547$ & $-0,092$ \\
\hline Zadovoljstvo_17 & $\begin{array}{l}\text { Bogatstvo } \\
\text { sportskih } \\
\text { sadržaja }\end{array}$ & 3,63 & 0,992 & $-0,272$ & $-0,370$ \\
\hline Zadovoljstvo_12 & $\begin{array}{c}\text { Turistička } \\
\text { signalizacija u } \\
\text { destinaciji }\end{array}$ & 3,58 & 1,030 & $-0,582$ & $-0,044$ \\
\hline Zadovoljstvo_22 & $\begin{array}{l}\text { Raznolikost } \\
\text { kulturnih } \\
\text { manifestacija }\end{array}$ & 3,58 & 0,862 & 0,018 & $-0,674$ \\
\hline Zadovoljstvo_23 & $\begin{array}{l}\text { Ukupni odnos } \\
\text { cijene i kvalitete }\end{array}$ & 3,55 & 0,989 & $-0,430$ & $-0,025$ \\
\hline Zadovoljstvo_19 & $\begin{array}{c}\text { Bogatstvo } \\
\text { sadržaja za } \\
\text { zabavu }\end{array}$ & 3,54 & 1,085 & $-0,425$ & $-0,521$ \\
\hline Zadovoljstvo_14 & $\begin{array}{l}\text { Opremljenost i } \\
\text { uređenost plaža }\end{array}$ & 3,53 & 1,085 & $-0,446$ & $-0,476$ \\
\hline Zadovoljstvo_20 & $\begin{array}{l}\text { Kvaliteta } \\
\text { lokalnog } \\
\text { prijevoza }\end{array}$ & 3,27 & 1,019 & $-0,202$ & $-0,368$ \\
\hline
\end{tabular}




\section{2 Rezultati multivarijatne statističke analize}

Rezultati procjene strukturnog modeliranja jednadžbama primjenom metode parcijalnih najmanjih kvadrata (PLS-SEM) prikazat će se u dva koraka. Prvo će se prikazati rezultati analize vanjskog mjernog strukturnog modela, a potom unutarnjeg mjernog strukturnog modela.

\subsubsection{Rezultati vanjskog reflektivnog i formativnog mjernog modela}

Procjena dosljednosti mjernog reflektivnog modela ispitana je analizom pouzdanosti i valjanosti manifestnih varijabli te egzogenih i endogenih latentnih konstrukata. Manifestne varijable s vanjskim faktorskim opterećenjem između 0,60 i 0,70 smatraju se prikladnima u eksploratornim istraživanjima (Nunnally, Bernstein, 1994). Standardizirana faktorska opterećenja manifestnih varijabli nalaze se $u$ intervalu od 0,313 i 0,848. Četiri manifestne varijable imaju vrijednost manju od 0,60 te su eliminirane iz daljnje analize.

U Tablici 2 prikazani se rezultati analize pouzdanosti reflektivnih latentnih konstrukata i varijable mjernih konstrukata pomoću izračuna vrijednosti koeficijenata unutarnje dosljednosti primjenom Cronbach alpha koeficijenta.

Tablica 2. Zbirni rezultati analize mjernog reflektivnog modela

\begin{tabular}{|c|c|c|c|c|c|c|}
\hline & & \multicolumn{2}{|c|}{ Konvergentna valjanost } & \multicolumn{2}{|c|}{$\begin{array}{l}\text { Unutarnja } \\
\text { dosljednosti }\end{array}$} & $\begin{array}{c}\text { Diskriminantna } \\
\text { valjanost }\end{array}$ \\
\hline $\begin{array}{l}\text { Latentne } \\
\text { varijable }\end{array}$ & $\begin{array}{l}\text { Manifestne } \\
\text { varijable }\end{array}$ & $\begin{array}{c}\text { Standardizirano } \\
\text { faktorsko } \\
\text { opterećenje }\end{array}$ & AVE & $\begin{array}{c}\text { Cronbach } \\
\alpha\end{array}$ & CR & $\begin{array}{c}\text { Fornell-Larcker; } \\
\text { Cross loadings; } \\
\text { HTMT }\end{array}$ \\
\hline \multirow{5}{*}{$\begin{array}{l}\text { Sadržaj } \\
\text { poruka na } \\
\text { društvenim } \\
\text { medijima }\end{array}$} & Sadržaj_1 & 0,695 & \multirow{5}{*}{0,525} & \multirow{5}{*}{0,776} & \multirow{5}{*}{0,846} & \multirow{5}{*}{ da } \\
\hline & Sadržaj_2 & 0,664 & & & & \\
\hline & Sadržaj_3 & 0,848 & & & & \\
\hline & Sadržaj_4 & 0,688 & & & & \\
\hline & Sadržaj_5 & 0,713 & & & & \\
\hline \multirow{5}{*}{$\begin{array}{l}\text { Stav prema } \\
\text { ugledu na } \\
\text { društvenim } \\
\text { medijima }\end{array}$} & Stav_1 & 0,747 & \multirow{5}{*}{0,518} & \multirow{5}{*}{0,770} & \multirow{5}{*}{0,842} & \multirow{5}{*}{ da } \\
\hline & Stav_2 & 0,680 & & & & \\
\hline & Stav_3 & 0,653 & & & & \\
\hline & Stav_5 & 0,669 & & & & \\
\hline & Stav_6 & 0,835 & & & & \\
\hline
\end{tabular}


J. Mušanović: Modeliranje utjecaja ugleda turističke destinacije prisutnog u društvenim medijima na... Zbornik Veleučilišta u Rijeci, Vol. 8 (2020), No. 1, pp. 77-101

\begin{tabular}{|c|c|c|c|c|c|c|}
\hline & & \multicolumn{2}{|c|}{ Konvergentna valjanost } & \multicolumn{2}{|c|}{$\begin{array}{l}\text { Unutarnja } \\
\text { dosljednosti }\end{array}$} & $\begin{array}{c}\text { Diskriminantna } \\
\text { valjanost }\end{array}$ \\
\hline $\begin{array}{l}\text { Latentne } \\
\text { varijable }\end{array}$ & $\begin{array}{l}\text { Manifestne } \\
\text { varijable }\end{array}$ & $\begin{array}{c}\text { Standardizirano } \\
\text { faktorsko } \\
\text { opterećenje }\end{array}$ & AVE & $\begin{array}{c}\text { Cronbach } \\
\alpha\end{array}$ & CR & $\begin{array}{c}\text { Fornell-Larcker; } \\
\text { Cross loadings; } \\
\text { HTMT }\end{array}$ \\
\hline \multirow{5}{*}{$\begin{array}{c}\text { Ugled } \\
\text { turističke } \\
\text { destinacije } \\
\text { na } \\
\text { društvenim } \\
\text { medijima }\end{array}$} & Ugled_1 & 0,705 & \multirow{5}{*}{0,541} & \multirow{5}{*}{0,789} & \multirow{5}{*}{0,855} & \multirow{5}{*}{ da } \\
\hline & Ugled_2 & 0,740 & & & & \\
\hline & Ugled_3 & 0,716 & & & & \\
\hline & Ugled_4 & 0,773 & & & & \\
\hline & Ugled_5 & 0,741 & & & & \\
\hline
\end{tabular}

*AVE - prosječna izlučena varijanca; CR - kompozitna pouzdanost; Cross loadings - unakrsna standardizirana faktorska opterećenja; HTMT - Heterotrait-Monotrait omjer korelacije.

Izvor: rezultati istraživanja

Razmotre li se vrijednosti Cronbach alpha koeficijenata latentnih konstrukata, može se zaključiti da se vrijednosti nalaze se $u$ intervalu od 0,770 do 0,789 što zadovoljava granice prihvatljivosti i pokazuju dobru pouzdanost, tj. visoki stupanj unutarnje stabilnosti i dosljednosti mjernih latentnih konstrukata. Kompozitna pouzdanost - CR - za sve latentne konstrukte vanjskog reflektivnog modela premašuje potrebni minimum od 0,708 , što znači da varijable dobro predstavljaju latentne konstrukte.

Provjeri diskriminantne valjanosti pristupilo se ispitivanjem Fornell-Larcker kriterija, unakrsnim standardiziranim faktorskim opterećenjima (Cross loadings) te Heterotrait-Monotrait omjerom korelacije (HTMT) čiji su rezultati prikazani u nastavku.

Tablica 3. Diskriminantna valjanost (Fornell-Larcker kriterij)

\begin{tabular}{|c|c|c|c|}
\hline & $\begin{array}{c}\text { Sadržaj poruka } \\
\text { na društvenim } \\
\text { medijima }\end{array}$ & $\begin{array}{c}\text { Stav prema } \\
\text { ugledu na } \\
\text { društvenim } \\
\text { medijima }\end{array}$ & $\begin{array}{c}\text { Ugled turističke } \\
\text { destinacije na } \\
\text { društvenim } \\
\text { medijima }\end{array}$ \\
\hline $\begin{array}{c}\text { Sadržaj poruka na društvenim } \\
\text { medijima }\end{array}$ & 0,724 & 0,720 & \\
\hline $\begin{array}{c}\text { Stav prema ugledu na } \\
\text { društvenim medijima }\end{array}$ & 0,357 & 0,367 & 0,735 \\
\hline $\begin{array}{c}\text { Ugled turističke destinacije na } \\
\text { društvenim medijima }\end{array}$ & 0,544 & & \\
\hline
\end{tabular}

Izvor: rezultati istraživanja 
Iz Tablice 3 vidljivo je da se vrijednosti svih unakrsnih standardizirana faktorskih opterećenja po varijablama latentnih konstrukata nalaze $u$ rasponu od 0,720 do 0,735 čime je potvrđeno da su vrijednosti prosječne izlučene varijance (AVE) svakog latentnog konstrukta veće od najvećih kvadrata korelacije drugih konstrukata.

Tablica 4. Diskriminantna valjanost (unakrsna standardizirana faktorska opterećenja - Cross Loadings)

\begin{tabular}{|c|c|c|c|}
\hline & $\begin{array}{c}\text { Sadržaj poruka na } \\
\text { društvenim medijima }\end{array}$ & $\begin{array}{c}\text { Stav prema ugledu na } \\
\text { društvenim medijima }\end{array}$ & $\begin{array}{c}\text { Ugled turističke destinacije } \\
\text { na društvenim medijima }\end{array}$ \\
\hline Sadržaj_1 & 0,695 & 0,294 & 0,249 \\
Sadržaj_2 & 0,664 & 0,173 & 0,356 \\
Sadržaj_3 & 0,848 & 0,370 & 0,500 \\
Sadržaj_4 & 0,688 & 0,310 & 0,343 \\
Sadržaj_5 & 0,713 & 0,156 & 0,447 \\
Stav_1 & 0,200 & 0,747 & 0,342 \\
Stav_2 & 0,158 & 0,680 & 0,248 \\
Stav_3 & 0,303 & 0,653 & 0,165 \\
Stav_5 & 0,296 & 0,669 & 0,218 \\
Stav_6 & 0,366 & 0,835 & 0,292 \\
Ugled_1 & 0,454 & 0,212 & 0,705 \\
Ugled_2 & 0,466 & 0,197 & 0,740 \\
Ugled_3 & 0,228 & 0,343 & 0,716 \\
Ugled_4 & 0,421 & 0,286 & 0,773 \\
Ugled_5 & 0,414 & 0,307 & 0,741 \\
\hline
\end{tabular}

Izvor: rezultati istraživanja

Analizom unakrsnih standardiziranih faktorskih opterećenja (Tablica 4) može se utvrditi da svaki reflektivni latentni konstrukt dijeli više varijance sa pridruženim manifestnim varijablama nego s preostalim reflektivnim latentnim konstruktima u model čime se također utvrđuje diskriminantna valjanost latentnih konstrukata. 
Tablica 5. Diskriminantna valjanost (Heterotrait-Monotrait omjer korelacije - HTMT)

\begin{tabular}{|c|c|c|c|}
\hline & $\begin{array}{c}\text { Sadržaj poruka } \\
\text { na društvenim } \\
\text { medijima }\end{array}$ & $\begin{array}{c}\text { Stav prema ugledu } \\
\text { na društvenim } \\
\text { medijima }\end{array}$ & $\begin{array}{c}\text { Ugled turističke } \\
\text { destinacije na } \\
\text { društvenim medijima }\end{array}$ \\
\hline $\begin{array}{c}\text { Sadržaj poruka na } \\
\text { društvenim medijima }\end{array}$ & $\begin{array}{c}0,487 \\
\text { Stav prema ugledu na } \\
\text { društvenim medijima }\end{array}$ & $0,375 ; 0,626]$ & 0,657 \\
\hline $\begin{array}{c}\text { Ugled turističke destinacije } \\
\text { na društvenim medijima }\end{array}$ & {$[0,569 ; 0,749]$} & $\begin{array}{c}0,458 \\
{[0,352 ; 0,583]}\end{array}$ & \\
\hline
\end{tabular}

Izvor: rezultati istraživanja

Vrijednosti Heterotrait-Monotrait omjera korelacije manje su od referentne vrijednosti 0,9, a gornje vrijednosti intervala pouzdanosti manje od 1 (Tablica 5). Može zaključiti da je prema svim prethodno navedenim kriterijima zadovoljena diskriminantna valjanost reflektivnih latentnih konstrukata.

U nastavku prikazani su pokazatelji kolinearnosti, signifikantnosti i relevantnosti mjernog vanjskog formativnog modela (Tablica 6). 
J. Mušanović: Modeliranje utjecaja ugleda turističke destinacije prisutnog u društvenim medijima na... Zbornik Veleučilišta u Rijeci, Vol. 8 (2020), No. 1, pp. 77-101

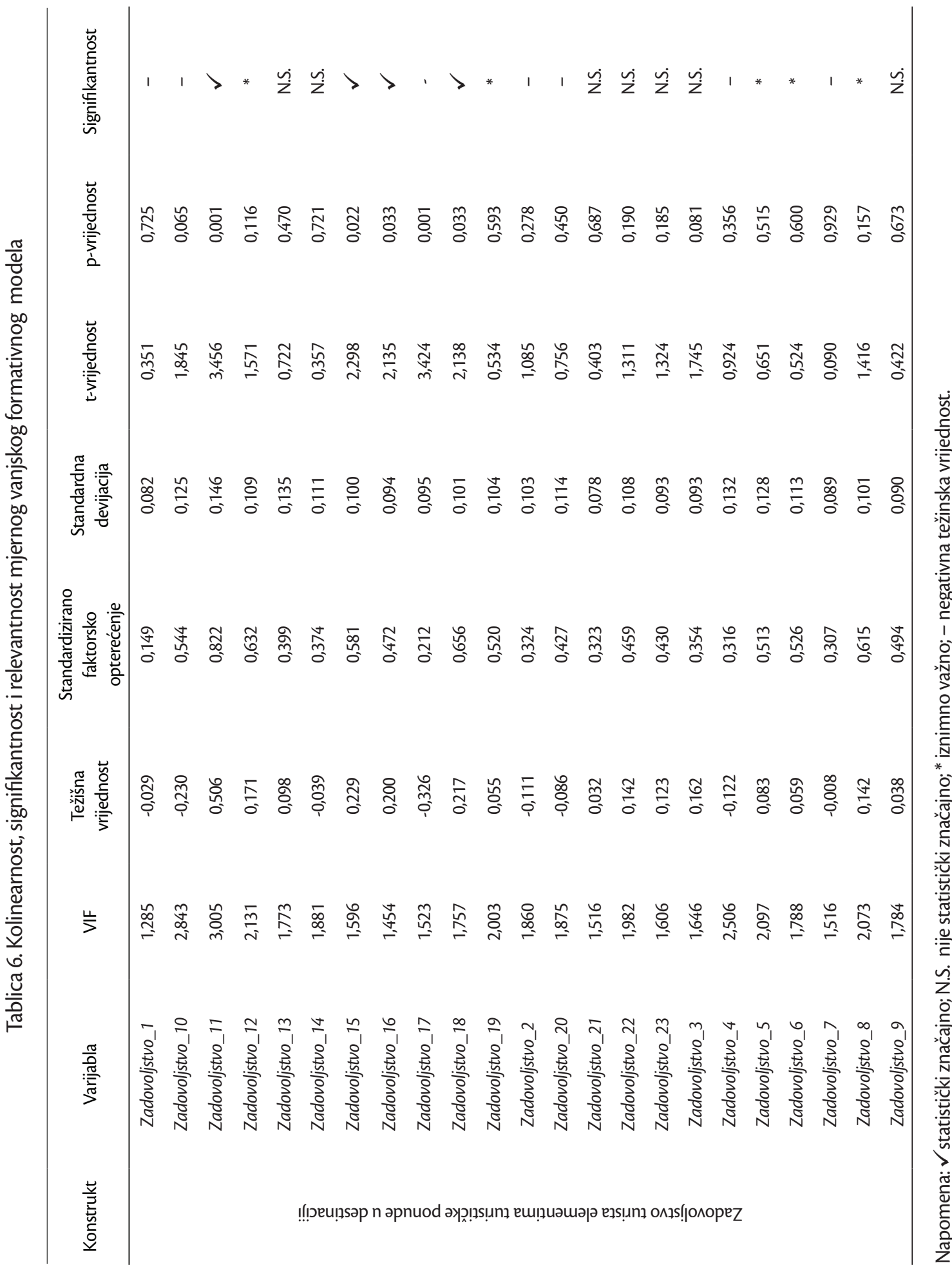


Pouzdanost formativnog latentnog konstrukta je ispitana testiranjem kolinearnosti između manifestnih varijabla latentnog konstrukta primjenom koeficijenta inflacije varijance (VIF). $\mathrm{Na}$ temelju rezultata može se zaključiti da se sve vrijednosti koeficijenata nalaze u referentnom intervalu između 0,02 i 5 , što znači da pretpostavka o kolinearnosti vanjskih koeficijenata nije narušena (Tablica 6). Također, statistička signifikantnost faktorskih opterećenja utvrđena je primjenom Bootstraping procedure na temelju 5000 poduzoraka i značajnosti na razini $p<0,05$. Iz Tablice 6 vidljivo je da su samo manifestne varijable Zadovoljstvo_11, Zadovoljstvo_15, Zadovoljstvo_16 i Zadovoljstvo_18 statistički značajne na razini od 0,05. Manifestne varijable koje imaju statistički značajnu negativnu težinsku vrijednost i pozitivno faktorsko opterećenje, interpretiraju u kontekstu negativnog utjecaja na temeljni latentni konstrukt (Orehovački, 2013) i eliminirat će se iz daljnje analize. Manifestne varijable koje imaju negativne težinske vrijednosti i faktorsko opterećenje manje od 0,500 također će se eliminirati iz daljnje analize. Manifestne varijable koje nisu statistički značajne i imaju faktorsko opterećenje veće od 0,500 zadržati će se i tumačit će se kao iznimno važne (Hair et al., 2017). Zaključno, u testiranje strukturnog modela ukupno će biti uključeno devet manifestnih varijabli.

\section{2.2 Rezultati unutarnjeg mjernog strukturnog modela}

Prije testiranja utjecaja latentnih konstrukata strukturnog modela ispitana je kolinearnost između latentnih konstrukata. Prema rezultatima, kolinearnost i vrijednost unutarnjih koeficijenata inflacije varijacije latentnih konstrukata iznose $u$ oba slučaja 1,147 , te se nalaze u granicama referentnih vrijednosti (od 0,2 do 5), što znači da ne postoji kolinearnost između egzogenih i endogenih latentnih konstrukata.

Dijagram puta strukturnog modela (Slika 1) prikazuje statistički značajne korelacije ključne za potvrđivanje hipoteza. Prema Cohenu (1988) uočavaju se snažne, umjerene i slabe povezanosti latentnih konstrukata.

Slika 1. Strukturni mjerni model

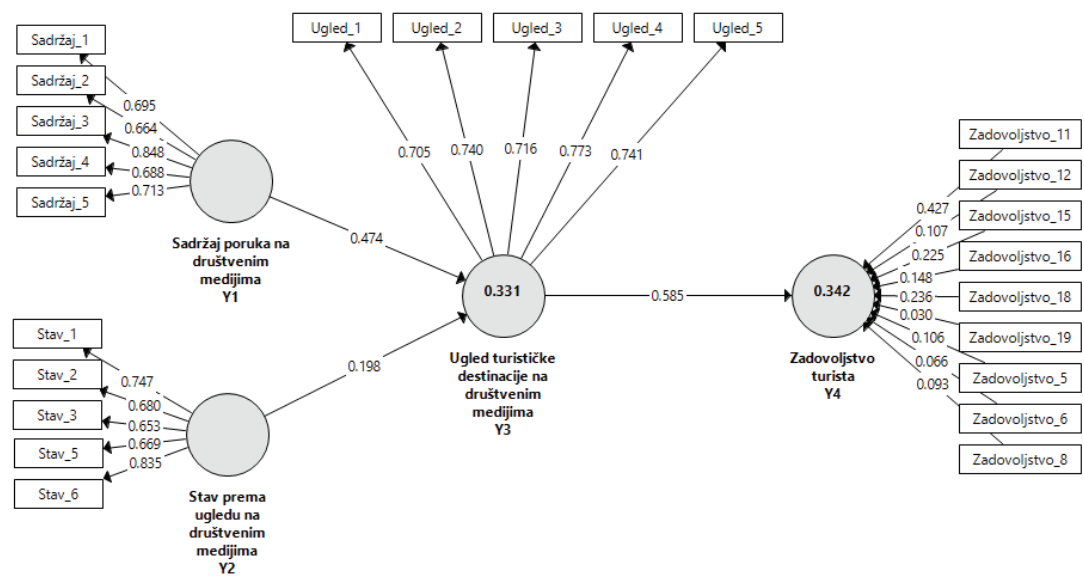

Izvor: rezultati istraživanja. 
Najsnažniji utjecaj uočava se između latentnih konstrukata ugled turističke destinacije na društvenim medijima i zadovoljstvo turista elementima turističke ponude (0,585). Umjereni utjecaj uočava se između latentnih konstrukata sadržaj poruka na društvenim medijima i ugled turističke destinacije na društvenim medijima $(0,474)$, a slabi utjecaj uočen je između latentnih konstrukata stav prema komentarima na društvenim medijima i ugled turističke destinacije na društvenim medijima $(0,198)$.

Korigirani koeficijent determinacije $\mathrm{R}^{2}$ zavisnih latentnih varijabli iznosi 0,331 i 0,342. Reflektivna zavisna latentna varijabla ugled turističke destinacije na društvenim medijima objašnjena je $s$ $33,1 \%$ varijance nezavisnim latentnim varijablama. Formativna zavisna latentna varijabla zadovoljstvo turista objašnjena je s 34,2 \% varijance nezavisnim latentnim varijablama. S obzirom na to da su endogene varijable objašnjene malim brojem egzogenih latentnih varijabli, vrijednosti korigiranog koeficijenata determinacije $\mathrm{R}^{2}$ ukazuju na umjerenu i dostatnu povezanost latentnih varijabli i reprezentativnost modela.

Prediktivna relevantnosti utvrđena je Blindfolding procedurom primjenom unakrsno validirane redudance izračunom Stone-Geisserov $Q^{2}$ pokazatelja. Vrijednosti $Q^{2}$ iznose 0,171 i 0,130 te su veće od nule i ukazuju na zadovoljavajuću razinu prediktivnog značaja modela puta.

Nadalje, uočava se veliki utjecaj učinka $\left(f^{2}=0,519\right)$ egzogenog latentnog konstrukta ugled turističke destinacije prisutan na društvenim medijima na zadovoljstvo turista. Srednji utjecaj uočava se između egzogenog latentnog konstrukta sadržaj poruka na društvenim medijima i endogenog latentnog konstrukta ugled turističke destinacije na društvenim medijima $\left(f^{2}=0,293\right)$. Slab utjecaj uočava se između egzogenog latentnog konstrukta stav prema komentarima na društvenim medijima i endogenog latentnog konstrukta ugled turističke destinacije na društvenim medijima $\left(f^{2}=0,051\right)$.

\section{ZAKLJUČAK}

Istraživanje korisnički generiranih sadržaja i recenzija na društvenim medijima u turizmu još uvijek je poprilično nov pristup. S obzirom na važnost recenzija na društvenim medijima pri donošenju odluka, praćenje ugleda na društvenim medijima, poboljšanje usluga i zadovoljstva turista na temelju povratnih informacija turista i korisnika nije više opcija već nužnost. Stoga je održavanje pozitivnog ugleda na društvenim medijima iznimno važno jer utječe na zadovoljstvo turista.

Prema rezultatima, prva hipoteza, Postoji statistički značajan utjecaj sadržaja poruka na ugleda turističke destinacije prisutnih u društvenim medijima, potvrđuje se zbog empirijske veze $(\beta=0,474 ; t=10,335)$ koja je statistički značajna na razini $p<0,01$. Populacija se s $99 \%$ vjerojatnosti nalazi u intervalu pouzdanosti od 0,368 do 0,553. Druga hipoteza, Postoji statistički značajan utjecaj stava prema komentarima na ugled turističke destinacije prisutnih u društvenim medijima, potvrđuje se. Empirijska je veza slaba, ali postojana $(\beta=0,198 ; t=4,404)$. Populacija se s $99 \%$ vjerojatnosti nalazi u intervalu od 0,099 do 0,279. Treća hipoteza, Postoji statistički značajan utjecaj ugleda turističke destinacije prisutnog u društvenim medijima na zadovoljstva turista, potvrđuje se. Empirijska veza statistički je značajna na razini $p<0,01$ te se opisuje kao je snažna veza ( $\beta=$ $0,585, t=13,335)$. Interval procjene populacije nalazi se s $99 \%$ vjerojatnosti u intervalu od 0,471 do 0,651 . 
$\mathrm{Na}$ temelju rezultata istraživanja može se zaključiti kako testirani strukturni model daje slične rezultate testiranja strukturnih odnosa među konceptima (Marchiori et al., 2013), iako se uspoređuju rezultati parametrijske i neparametrijske statistike. Prema pokazateljima valjanosti, navedeni modeli mogu se smatrati valjanima i pouzdanima u mjerenju utjecaja ugleda turističke destinacije prisutnog $u$ društvenim medijima $i$ kao prethodnice zadovoljstva turista elementima turističke ponude. Usporede li se rezultati istraživanja TOMAS ljeto 2017. na primjeru Istarske županije i rezultata istraživanja rada, može se zaključiti da su rezultati pokazali vrlo slične razine zadovoljstva elementima turističke ponude. Turisti u oba istraživanja izrazili vrlo visok $i$ visok stupanj zadovoljstva elementima turističke ponude. Također, usporedba utjecaja ugleda turističke destinacije na zadovoljstvo turista moguća je takozvanim online i offline ugledom turističke destinacije. Recentno istraživanje autora Su et al. (2018) potvrdilo je direktnu, značajnu i jaku vezu ugleda turističke destinacije sa zadovoljstvom turista $(0,603)$.

Unatoč nastojanju da se osigura kvalitetno empirijsko istraživanje, ono ima nekoliko ograničenja koje treba uzeti u obzir pri interpretaciji i generalizaciji rezultata, a odnose se na odabir turističke destinacije, vremensko razdoblje provedenog empirijskog istraživanja, uzorak ispitanika i generalizaciju rezultata. Navedenih ograničenja treba biti svjestan, ali ona ne bi trebala umanjiti značaj dobivenih rezultata i kvalitetu donesenih zaključaka. Štoviše, njihova detaljna elaboracija trebala bi dodatno potkrijepiti prednosti i nedostatke donesenih metodoloških izbora.

Doprinos rada ogleda se u razvoju i povezivanju znanstvene misli koncepta ugleda turističke destinacije na društvenim medijima i zadovoljstva turista. Rezultati istraživanja od koristi su svim dionicima u turizmu koji nastoje zadržati i stvoriti lojalne turiste, privući nove turiste, povećati konkurentnost turističke destinacije. Destinacijska marketing organizacija (DMO) trebala bi se koristiti prednostima društvenih medija za suradnju s destinacijskim menadžmentom, uzimajući u obzir iskustva i napore svih članova zajednice destinacije. Platforme elektroničkog učenja, namijenjene osposobljavanju i obrazovanju interesno-utjecajnim skupinama turizma, trebale bi razmotriti ulaganje u programe obuke koji uzimaju u obzir reputaciju turističke destinacije na društvenim medijima i mrežnim sjedištima, kao ključ saznanja potencijalnih očekivanja turista (klijenata) u svrhu povećanja zadovoljstva turista, prodaje, profitabilnost i konkurentnosti.

\section{LITERATURA}

Agyeiwaah, E. et al. (2016) 'Make a customer, not a sale: Tourist satisfaction in Hong Kong', Tourism Management. Pergamon, 57, pp. 68-79. doi: 10.1016/J.TOURMAN.2016.05.014.

Akama, J. S., Kieti, D. M. (2003) 'Measuring tourist satisfaction with Kenya's wildlife safari: a case study of Tsavo West National Park', Tourism Management. Pergamon, 24(1), pp. 73-81. doi: 10.1016/S0261-5177(02)00044-4.

Alegre, J., Cladera, M. (2006) 'Repeat Visitation in Mature Sun and Sand Holiday Destinations', Journal of Travel Research. Sage PublicationsSage CA: Thousand Oaks, CA, 44(3), pp. 288-297. doi: 10.1177/0047287505279005.

Ammissah, E. F. (2013) 'Tourist Satisfaction with Hotel Services in Cape Coast and Elmina, Ghana', American Journal of Tourism Management. Available at: http://article.sapub.org/10.5923.s.tourism.201304.03.html (Accessed: 24 July 2018). 
Cacioppo, J. T., Petty, R. E. and Morris, K. J. (1983) 'Effects of need for cognition on message evaluation, recall, and persuasion.', Journal of Personality and Social Psychology, 45(4), pp. 805-818. doi: 10.1037/0022-3514.45.4.805.

Cenfetelli, R. T., Bassellier, G. (2009) 'Interpretation of Formative Measurement in Information Systems Research', MIS quarerly, 33(4), pp. 689-707.

Chadee, D. D., Mattsson, J. (1996) 'An Empirical Assessment of Customer Satisfaction in Tourism', The Service Industries Journal. Frank Cass, 16(3), pp. 305-320. doi: 10.1080/02642069600000030.

Chen, C.-F., Tsai, D. (2007) 'How destination image and evaluative factors affect behavioral intentions?', Tourism Management. Pergamon, 28(4), pp. 1115-1122. doi: 10.1016/J.TOURMAN.2006.07.007.

Chen, Y., Zhang, H., Qiu, L. (2013) 'A Review on Tourist Satisfaction of Tourism Destinations', in Zhang, R. and Zhang, J. (eds) LISS 2012. Berlin, Heidelberg: Springer Berlin Heidelberg, pp. 593-604. doi: 10.1007/978-3-642-32054-5_83.

Cheung, M. Y. et al. (2009) 'Credibility of Electronic Word-of-Mouth: Informational and Normative Determinants of On-line Consumer Recommendations', International Journal of Electronic Commerce, 13(4), pp. 9-38. doi: 10.2753/ JEC1086-4415130402.

Christou, E. (2007) Productivity in Tourism: Fundamentals and Concepts for Achieving Growth and competitiveness. Berlin: Erich Schmidt Verlag \& Co KG.

Cohen, J. (1988) Statistical power analysis for the Behavioral Sciences. 2nd ed. New York.

Darwish, A., Burns, P. (2019) 'Tourist destination reputation: an empirical definition', Tourism Recreation Research. doi: 10.1080/02508281.2018.1558754.

Deutsch, M., Gerard, H. B. (1955) 'A study of normative and informational social influences upon individual judgment.', The Journal of Abnormal and Social Psychology, 51(3), pp. 629-636. doi: 10.1037/h0046408.

Díaz, M. R., Rodríguez, T. F. E. (2017) 'Determining the reliability and validity of online reputation databases for lodging', Journal of Vacation Marketing. doi: 10.1177/1356766717706103.

Dolphin, R. R. (2004) 'Corporate reputation - a value creating strategy', Corporate Governance: The international journal of business in society, 4(3), pp. 77-92. doi: 10.1108/14720700410547521.

Einwiller, S. (2003) Vertrauen durch Reputation im elektronschen Handel. Wiesbaden: Deutscher Universitätsverlag.

Fornell, C., Bookstein, F. L. (1982) 'Two Structural Equation Models: LISREL and PLS Applied to Consumer Exit-Voice Theory', Journal of Marketing Research. American Marketing Association, 19(4), pp. 440-452. doi: 10.2307/3151718.

Foster, D. (2000) 'Measuring customer satisfaction in the tourism industry', in Third International \& Sixth National Research Conference on Quality Management, The Center for Management Quality Research at RMIT University, Australia, pp. 1-9.

Fotis, J., Buhalis, D., Rossides, N. (2012) 'Social Media Use and Impact during the Holiday Travel Planning Process', in Fuchs, M. Ricci, F., and Cantoni, L. (eds) Information and Communication Technologies in Tourism 2012. Vienna: Springer Vienna, pp. 13-24.

Golob, Marino, Sirotić, T., Golob, Martin (2014) 'Istraživanje kvalitete i razine zadovoljstva turista turističkom ponudom', Zbornik Veleučilišta u Rijeci, 2(1), pp. 27-40.

Haber, S., Lerner, M. (1999) 'Correlates of Tourist Satisfaction', Annals of Tourism Research. Pergamon, 26(1), pp. 197-201. doi: 10.1016/S0160-7383(98)00060-7.

Hair, J. F. et al. (2012) 'The Use of Partial Least Squares Structural Equation Modeling in Strategic Management Research: A Review of Past Practices and Recommendations for Future Applications', Long Range Planning, 45(5-6), pp. 320340. doi: 10.1016/j.lrp.2012.09.008.

Hair, J. F. J. et al. (2017) A Primer on Partial Least Squares Structural Equation Modeling (PLS-SEM). Second. Los Angeles: Sage Publications.

Hair, J. F., Ringle, C. M. and Sarstedt, M. (2011) 'PLS-SEM: Indeed a silver bullet', Journal of Marketing Theory and Practice, 19(2), pp. 139-151. doi: 10.2753/MTP1069-6679190202. 


\section{J. Mušanović: Modeliranje utjecaja ugleda turističke destinacije prisutnog u društvenim medijima na... Zbornik Veleučilišta u Rijeci, Vol. 8 (2020), No. 1, pp. 77-101}

Hapenciuc, C. V., Condratov, I. (2007) 'Theoretical framework for quality evaluation of tourism-related websites services', Economy Informatics, 1(4), pp. 52-58.

Hastak, M., Park, J.-W. (1990) 'Mediators of Message Sidedness Effects on Cognitive Structure For Involved and Uninvolved Audiences', Advances in Consumer Research, 17(17), pp. 329-336. Available at: https://www.acrwebsite.org/search/ view-conference-proceedings.aspx?ld=9832 (Accessed: 1 May 2018).

Henseler, J., Ringle, C. M., Sinkovics, R. R. (2009) 'The Use of Partial Least Squares Path Modeling in International Marketing', New Challenges to International Marketin Advances in International Marketing, 20, pp. 277-319. doi: 10.1108/S1474-7979(2009)0000020014.

Jensen, $\varnothing$., Li, Y., Uysal, M. (2017) 'Visitors' satisfaction at managed tourist attractions in Northern Norway: Do on-site factors matter?', Tourism Management, 63, pp. 277-286. doi: 10.1016/j.tourman.2017.06.025.

Kamins, M. A., Marks, L. J. (1988) 'An Examination into the Effectiveness of Two-Sided Comparative Price Appeals', Journal of the Academy of Marketing Science. Sage PublicationsSage CA: Thousand Oaks, CA, 16(2), pp. 64-71. doi: $10.1177 / 009207038801600210$.

Kemp, S. (2019) Digital 2019: GLobal Digital Overview, Datareportal. Available at: https://datareportal.com/reports/ digital-2019-global-digital-overview .

Kim, S., Mattila, A. S. (2011) 'An examination of electronic video clips in the context of hotel Websites', International Journal of Hospitality Management, 30(3), pp. 612-618. doi: https://doi.org/10.1016/j.ijhm.2010.11.005.

Kozak, M. (2001) 'Comparative assessment of tourist satisfaction with destinations across two nationalities', Tourism Management. Pergamon, 22(4), pp. 391-401. doi: 10.1016/S0261-5177(00)00064-9.

Kozak, M., Rimmington, M. (2000) 'Tourist satisfaction with Mallorca, Spain, as an off-season holiday destination', Journal of Travel Research, 38(3), pp. 260-269. doi: 10.1177/004728750003800308.

Leblanc, G. (1992) 'Factors Affecting Customer Evaluation of Service Quality in Travel Agencies: An Investigation of Customer Perceptions', Journal of Travel Research. Sage PublicationsSage CA: Thousand Oaks, CA, 30(4), pp. 10-16. doi: $10.1177 / 004728759203000402$.

LeBlanc, G., Nguyen, N. (1996) 'Cues used by customers evaluating corporate image in service firms: An empirical study in financial institutions', International Journal of Service Industry Management, 7(2), pp. 44-56.

Lee, C.-F. (2015) 'Tourist satisfaction with factory tour experience', International Journal of Culture, Tourism and Hospitality Research, 9(3), pp. 261-277. doi: 10.1108/IJCTHR-02-2015-0005.

Loureiro, S. M. C., Kastenholz, E. (2011) 'Corporate reputation, satisfaction, delight, and loyalty towards rural lodging units in Portugal', International Journal of Hospitality Management. Elsevier Ltd, 30(3), pp. 575-583. doi: 10.1016/j. ijhm.2010.10.007.

Macintosh, G. (2002) 'Building Trust and Satisfaction in Travel Counselor/Client Relationships', Journal of Travel \& Tourism Marketing. Taylor \& Francis Group , 12(4), pp. 59-74. doi: 10.1300/J073v12n04_04.

Marchiori, E. et al. (2010) 'Towards a tourism destination reputation model. A first step', in Proceedings of the 6th International Conference - Thought Leaders in Brand Management. Lugano - Switzerland, pp. 921-930.

Marchiori, E., Cantoni, L. (2012) 'The Online Reputation Construct: Does it Matter for the Tourism Domain? A Literature Review on Destinations' Online Reputation', Information Technology \& Tourism, 13(3), pp. 139-159. doi: 10.3727/1 $09830512 \times 13283928066715$.

Marchiori, E., Cantoni, L., Fesenmaier, D. R. (2013) 'What did they say about us? Message Cues and Destination Reputation in Social Media', in Cantoni, L. and Xiang, Z. (eds) Information and Communication Technologies in Tourism 2013. Springer Berlin Heidelberg, pp. 170-182. doi: 10.1007/978-3-642-36309-2.

Marchiori, E., Inversini, A., Cantoni, L. (2011) 'Classifying online conversations about Tourism Destinations. A tourist perspective., in Proceedings of the 7th international conference: Thought leaders in brand management. Lugan Switzerland, pp. 165-175. 
Marinao Artigas, E., Vilches-Montero, S. and Chasco Yrigoyen, C. (2015) 'Antecedents of tourism destination reputation: The mediating role of familiarity', Journal of Retailing and Consumer Services, 26, pp. 147-152. doi: 10.1016/j. jretconser.2015.06.005.

Marinao, E., Chasco, C., Torres, E. (2012) 'Trust in Tourist Destinations. The Role of Local Inhabitants and Institutions Confianza Hacia Los Destinos Turísticos', Academia, Revista Latinoamericana de Administración, 51, pp. 27-47.

Micera, R., Crispino, R. (2017) 'Destination web reputation as "smart tool” for image building: the case analysis of Naples city-destination', International Journal of Tourism Cities, 3(4), pp. 406-423. doi: https://doi.org/10.1108/IJTC-112016-0048.

Mingchuan, Z. (2015) 'The Reputation Crisis at the Tourism Destination: Connotation, Types and Management Strategies', International Journal of Liberal Arts and Social Science, 3(6), pp. 35-40.

Minghetti, V., Celotto, E. (2015) 'Destination Web reputation: Combining explicit and implicit popularity to build an integrated monitoring system', E-review of Tourism Research, 6, pp. 1-5.

Morgan, N., Pritchard, A. and Pride, R. (2011) Destination brands: Managing place reputation. 3rd Editio. Amsterdam: Elsevier.

Nunnally, J. C., Bernstein, I. H. (1994) Psychometic Theory. 3rd Editio. New York: McGRAW-HILL.

Okello, M. M., Yerian, S. (2009) 'Tourist satisfaction in relation to attractions and implications for conservation in the protected areas of the Northern Circuit, Tanzania', Journal of Sustainable Tourism. Taylor \& Francis Group , 17(5), pp. 605-625. doi: 10.1080/09669580902928450.

Orehovački, T. (2013) Metodologija vrjednovanja kvalitete u korištenju aplikacijama WEB 2.0. Sveučilište u Zagrebu.

Pizam, A., Neumann, Y., Reichel, A. (1978) 'Dimentions of tourist satisfaction with a destination area', Annals of Tourism Research. Pergamon, 5(3), pp. 314-322. doi: 10.1016/0160-7383(78)90115-9.

Pruzan, P. (2001) 'Corporate Reputation Image and Identity', Corporate Reputation Review, 4(1), pp. 50-51.

Puh, B. (2014) 'Destination image and Tourism Satisfaction: the Case of Mediterannean Destination', Mediterannean Journal of Social Sciences, 5(13), pp. 538-544. Available at: https://www.bib.irb.hr/897624 (Accessed: 20 July 2018).

Ringle, C. M. et al. (2009) On the use of formative measurement specifications in structural equation modeling: A Monte Carlo simulation study to compare covariance-based and partial least squares model estimation methodologies, Research Memoranda from Maastricht (METEOR). Available at: https://mpra.ub.uni-muenchen.de/15390/ (Accessed: 20 April 2018).

Ringle, C. M., Sarstedt, M., Straub, D. (2012) 'A Critical Look at the Use of PLS-SEM in MIS Quarterly', MIS Qarterly, 36(1), pp. iii-xiv. Available at: https://papers.ssrn.com/sol3/papers.cfm?abstract_id=2176426.

Ryan, C. (1994) Researching Tourist Satisfaction: Issues, Concepts Problem. London: Internationa Thomson Business Press.

Saayman, M. et al. (2018) 'Tourist satisfaction and subjective well-being: An index approach', International Journal of Tourism Research. Wiley-Blackwell, 20(3), pp. 388-399. doi: 10.1002/jtr.2190.

Soldić Frleta, D., Smolčić Jurdana, D. (2018) 'Seasonal variation in urban tourist satisfaction', Tourism Review. Emerald Publishing Limited. doi: 10.1108/TR-09-2017-0148.

De Souza, S. C., Costa Machado, D. F. (2017) 'Use and Influence of Social Media on Trip Planning: a quantitative study', Revista Tourismo em Analise - RTA, 28(2), pp. 254-270.

Spence, M. (1973) 'Spence 1973.pdf', The Quarterly Journal of Economics, 87(3), pp. 355-375.

Su, L., Huang, Y., Hsu, M. (2018) 'Unraveling the impact of destination reputation on place attachment and behavior outcomes among Chinese urban tourists', Journal of Hospitality and Tourism Insights. Emerald Publishing Limited. doi: 10.1108/JHTI-11-2017-0026.

Swinyard, W. R. (1981) 'The Interaction between Comparative Advertising and Copy Claim Variation', Journal of Marketing Research. American Marketing Association, 18(2), pp. 175-186. doi: 10.2307/3150952. 
Triantafillidou, A., Petala, Z. (2016) 'The Role Of Sea-Based Adventure Experiences In Tourists' Satisfaction and Behavioral Intentions', Journal of Travel \& Tourism Marketing. Routledge, 33(sup1), pp. 67-87. doi: 10.1080/10548408.2015.1008667.

Udit, C., Kalyan, S. S. (2017) 'Factors Affecting Customers' Accommodation Satisfaction and Service Quality in the Hotel Industry of Rural West Bengal', LBS Journal of Management \& Research. Diva Enterprises, 15(1), pp. 34-47. Available at: http://www.indianjournals.com/ijoraspx?target=ijor:lbsjmr\&volume=15\&issue=1\&article=004 (Accessed: 24 July 2018).

UNWTO (2019) International Tourism Highlights, 2019 Edition, International Tourism Highlights, 2019 Edition. World Tourism Organization (UNWTO). doi: 10.18111/9789284421152.

Urška Starc, P. et al. (2019) 'Tourism 4.0: Challenges in Marketing a Paradigm Shift', in IntechOpen (ed.) Consumer Behavior and Marketing.

Vengesayi, S. (2003) 'A conceptual model of tourism destination competitiveness and attractiveness', in ANZMAC Conference Proceedings Adelaide 1-3 December 2003, pp. 637-647.

Vilares, M. J., Almeida, M. H., Coelho, P. S. (2010) 'Comparison of likelihood and PLS estimators for structural equation modeling: A simulation with customer satisfaction data', in Vinzi, V. E. et al. (eds) Handbook of Partial Least Squares. Heidelberg: Springer, pp. 289-305.

We Are Social (2019) Digital 2019: Global Digital Yearbook - DataReportal - Global Digital Insights. Available at: https://datareportal.com/reports/digital-2019-global-digital-yearbook (Accessed: 3 October 2019).

Wu, H.-C., Ko, Y.J. (2013) 'Assessment of Service Quality in the Hotel Industry', Journal of Quality Assurance in Hospitality \& Tourism. Routledge, 14(3), pp. 218-244. doi: 10.1080/1528008X.2013.802557.

Xiang, Z., Gretzel, U. (2010) 'Role of social media in online travel information search', Tourism Management. Elsevier Ltd, 31(2), pp. 179-188. doi: 10.1016/j.tourman.2009.02.016.

Yoon, E., Guffey, H. J. and Kijewski, V. (1993) 'The effects of information and company reputation on intentions to buy a business service', Journal of Business Research, 27(3), pp. 215-228. doi: 10.1016/0148-2963(93)90027-M.

Yu, L., Goulden, M. (2006) 'A comparative analysis of international tourists' satisfaction in Mongolia', Tourism Management. Pergamon, 27(6), pp. 1331-1342. doi: 10.1016/J.TOURMAN.2005.06.003. 


\title{
MODELING THE IMPACT OF TOURISM DESTINATION REPUTATION PRESENTED BY SOCIAL MEDIA ON THE TOURIST SATISFACTION
}

\author{
Jelena Mušanović \\ PhD, Postdoctoral Researcher, Faculty of Tourism and Hospitality Management, \\ University of Rijeka, Primorska 42, 51410 Opatija, Croatia. e-mail: jelenak@fthm.hr
}

\begin{abstract}
Before the appearance of user-generated content (UGC), sharing personal travel experiences through social media applications was limited to a narrow circle of friends and family. Today, tourists (social media users) exchange opinions via modern media online and shape the tourism destination reputation, thus affecting the travel decision of potential tourists. The purpose of this study is to examine the tourism destination reputation on social media and its impact on tourist satisfaction. The empirical research was conducted on the western coast of Istria (Croatia), using data from a survey of a sample of 305 tourists who were informed about the tourist destination on social media before traveling to the destination. Partial least squares were used to assess the structural model and impact of tourism destination reputation on social media on tourist satisfaction. The structural model is considered as a valid and reliable instrument for measuring the impact of tourism destination reputation on social media on tourist satisfaction. The results of this study and the proposed conceptual model provide a basis for future research and for the continuous monitoring and improving of the tourism destination reputation on social media and tourist satisfaction with the elements of tourism supply.
\end{abstract}

Key words: tourism destination reputation, tourist satisfaction, social media, modeling, multivariate statistical analysis 